\title{
English and Russian Genitive Alternations: A Study in Construction Typology
}

\author{
Sergei Monakhov \\ Friedrich Schiller University Jena \\ Jena, Germany
}

\begin{abstract}
There is little doubt that one of the most important areas of future research within the framework of Construction Grammar will be the comparative study of constructions in different languages of the world. One significant gain that modern Construction Grammar can make thanks to the cross-linguistic perspective is finding a clue to some contradictory cases of construction alternation. The aim of the present paper is to communicate the results of a case study of two pairs of alternating constructions in English and Russian: s-genitive (SG) and of-genitive (OG) in English and noun + noun in genitive case (NNG) and relative adjective derived from noun + noun (ANG) in Russian. It is evident that the long years of elaborate scientific analysis have not yielded any universally accepted view on the problem of English genitive alternation. There are at least five different accounts of this problem: the hypotheses of the animacy hierarchy, given-new hierarchy, topic-focus hierarchy, endweight principle, and two semantically distinct constructions. We hypothesised that in this case the comparison of the distribution of two English and two Russian genitives could be insightful. The analysis presupposed two consecutive steps. First, we established an inter-language comparability of two pairs of constructions in English and Russian. Second, we tested the similarity of intra-language distribution of each pair of constructions from the perspective of the animacy hierarchy. For these two purposes, two types of corpora were used: (1) a translation corpus consisting of original texts in one language and their translations into one or more languages; and (2) national corpora consisting of original texts in two respective languages. It was established that in both languages, the choice between members of an alternating pair is governed by the rules of animacy hierarchisation. Additionally, it was possible to disprove the idea that the animacy hierarchy is necessarily based on the linearisation hierarchy. Two Russian constructions are typologically aligned with their English counterparts, not on the grounds of the linear order of head and modifier but on the grounds of structural similarity. The English SG and Russian NNG construction are diametrically opposed in terms of word order. However, they reveal the same underlying structure of the inflectional genitive as contrasted with the analytical genitive of the Russian ANG and the English OG. These findings speak strongly in favour of the animacy hierarchy account of English genitive alternation.
\end{abstract}

Keywords: construction grammar, genitive alternation, contrastive linguistics, s-genitive, of-genitive, construction typology, corpus linguistics

\section{For Citation:}

Monakhov, Sergei. 2020. English and Russian genitive alternations: A study in construction typology. Russian Journal of Linguistics 24 (1). 96-116. DOI: 10.22363/2687-0088-2020-241-96-116. 
Научная статья

\title{
Генитивные обороты в английском и русском языках: опыт типологии конструкций
}

\author{
Сергей Монахов \\ Йенский университет имени Фридриха Шиллера \\ Йена, Германия
}

\begin{abstract}
Аннотация
Нет сомнений в том, что одним из важнейших направлений будущих исследований в рамках грамматики конструкций станет сравнительное изучение конструкций в разных языках мира. Существенным вкладом в лингвистику, который грамматика конструкций может сделать в рамках типологических исследований, является разрешение некоторых противоречивых случаев чередования конструкций. Цель настоящей работы заключается в представлении результатов исследования дистрибуции и функционирования двух пар конструкций в английском и русском языках: s-genitive (SG) и of-genitive (OG) в английском языке и существительное + существительное в родительном падеже (NNG) и относительное прилагательное, производное от существительного + существительное (ANG) в русском языке. К сожалению, долгие годы научных поисков не сформировали единого общепринятого взгляда на проблему чередования двух генитивных оборотов английского языка. Существует как минимум пять различных гипотез на этот счет, каждая из которых принимает в расчет один из следующих признаков: одушевленность, информационная структура, актуальное членение, синтаксическое устройство и семантические различия. Мы предположили, что в этом сложном случае сравнение двух английских и двух русских генитивных оборотов поможет найти решающие доводы в пользу одной из этих гипотез. Анализ предполагал два последовательных этапа. Вопервых, мы установили правомерность межъязыкового сравнения этих парных конструкций в английском и русском языках; во-вторых, проанализировали внутриязыковое распределение каждой пары конструкций с точки зрения иерархии одушевленности. Для этих двух целей были использованы два типа корпусов: (1) переводческий корпус, состоящий из оригинальных текстов на одном языке и их переводов на один или несколько языков; и (2) национальные корпусы, состоящие из оригинальных текстов на двух соответствующих языках. Мы установили, что в обоих языках выбор между членами чередующейся пары конструкций регулируется правилами иерархии одушевленности. Кроме того, нам удалось опровергнуть идею о том, что иерархия одушевленности обязательно основана на иерархии линеаризации. Две русские конструкции типологически подобны своим английским аналогам не на основании сходства линейного порядка определения и определяемого слова, а на основании структурного сходства. Английская конструкция SG и русская конструкция NNG диаметрально противоположны по порядку слов, однако они выявляют одну и ту же глубинную структуру флективного генитива, противоположного аналитическому генитиву русской ANG и английской OG. Эти данные убедительно свидетельствуют в пользу иерархии одушевленности как основного фактора чередования двух генитивных оборотов английского языка.
\end{abstract}

Ключевые слова: грамматика конструкиий, генитивное чередование, s-genitive, of-genitive, типология конструкций, корпусная лингвистика

\section{For Citation:}

Monakhov, Sergei. 2020. English and Russian genitive alternations: A study in construction typology. Russian Journal of Linguistics 24 (1). 96-116. DOI: 10.22363/2687-0088-2020-24-196-116. 


\section{Introduction}

Construction Grammar is the study of symbolic pairings of form and meaning that are characterised by structural or semantic and pragmatic idiosyncrasies as well as a high level of entrenchment in language [Croft 2001; Goldberg 2006; Langacker 2009]. Recently, Construction Grammar has become one of the most prominent frameworks in linguistics research. The theory's emergence was foreshadowed in the 1980s, when Pawley and Syder proposed 'lexicalized sentence stems', an analogous term that has not become popular [Pawley and Syder 1983], and Filmore et al. described 'minor constructions' or 'familiar pieces unfamiliarly arranged' [Filmore et al. 1988]. Since 1995, when Goldberg's seminal book outlined the theoretical underpinnings of Construction Grammar, linguists have performed extensive research. They first compiled an inventory of the possible types of constructions and then charted an entire network of constructions that is arguably capable of embracing the entire language domain and explaining every phenomenon within it, from morpheme to discourse, i.e. from more substantive constructions to more schematic ones [see Hilpert 2014 and Diessel 2019 for review]. The so-called 'dictionaries of constructions' or 'constructicons' are currently being developed for several languages, e.g. German, Swedish, Russian and English (cf. Lyngfelt et al. 2018).

There is little doubt that one of the most important areas of future research within the framework of Construction Grammar will be the comparative study of constructions in different languages of the world. By that we do not mean some kind of item-specific corpus-based contrastive analysis that is enjoying considerable popularity right now [Gast 2015], but rather a whole new area of study that can be called Construction Typology. Linguistic typology examines the worldwide variations of linguistic structures, classifies them into types, and tries to make generalisations about which types are universally preferred and why. Similarly, Construction Typology will explore global variations in types of constructions and associate them with certain construction universals. In other words, the language-specific constructions will be analysed and compared to gain insights into Universal Construction Grammar.

One significant gain that modern Construction Grammar can make thanks to the cross-linguistic perspective is finding a clue to some contradictory cases of construction alternation. In such cases, competing motivations sometimes make it impossible to explain which factors trigger the alternation or, even worse, determine whether it is an alternation or the coexistence of two largely independent constructions. A theory of alternation that can account for the distribution of a pair of competing constructions in one language and of a pair of related constructions that did not result from a loan translation in other language should be regarded as more insightful because it provides typological evidence.

To the best of our knowledge, little research has been conducted in this area. The aim of the present paper is to communicate the results of a case study of two pairs of alternating constructions in English and in Russian. 


\section{English genitive alternation}

The English genitive alternation has been studied extensively. It is one of the most famous alternating pairs in English and is on par with dative alternation, active and passive alternation, verb-particle constructions alternation, will versus going to alternation, and some others.

Researchers have focused on the distribution or partial paraphrase relationship [Goldberg 2002] of the $s$-genitive (or Saxon genitive) and the of-genitive (or ofconstruction):

(1) [NP modifier 's $\left.\mathrm{N}_{\text {head }}\right]$ heart's heart

(2) [Nhead of $\left.\mathrm{NP}_{\text {modifier }}\right]$ heart of heart

The investigation of the semantics and the distribution of two constructions has resulted in the five most prominent hypotheses [see Stefanowitsch 1998 for review]:

(a) The hypothesis of the animacy hierarchy predicts that the $s$-genitive is used where the referent of the modifier is higher up in the hierarchy than the head. In contrast, the of-genitive is used where the referent of the head is higher up in the hierarchy than the modifier [Jespersen 1949, Hawkins 1981, Deane 1992].

(b) The hypothesis of the given-new hierarchy predicts that the $s$-genitive is used where the referent of the modifier is given and the referent of the head is in focus. On the other hand, the of-genitive is used where the referent of the head is given and that of the modifier is new [Altenberg 1980, Standwell 1982].

(c) The hypothesis of the topic-focus hierarchy predicts that the $s$-genitive is used where the modifier is more topical and the head is in focus. In contrast, the ofgenitive is used where the head is more topical and the modifier is in focus [Osselton 1988, Jørgensen 1984].

(d) The hypothesis of the end-weight principle predicts that $s$-genitive is used where the modifier is shorter than the head. On the other hand, the of-genitive is used where the head is shorter than the modifier [Altenberg 1980, Hawkins 1994].

The aforementioned approaches are all based on the notion of a linearisation hierarchy [Siewierska 1988] and presuppose that semantical relations encoded by both constructions can be treated as identical. Stefanowitsch [1998] provides the fifth semantic-based account of the problem:

e) The $s$-genitive and of-genitive are two semantically distinct constructions. The former encodes kinship and social relations as well as possession while the latter encodes taxonomic and meronymic relations [see also Gries and Stefanowitsch 2004, Stefanowitsch 2003].

It is evident that the long years of elaborate scientific analysis have not yielded any universally accepted view of the problem of English genitive alternation. Many competing motivations are at work at the same time, and this situation makes any 
predictions about the actual choice between the two constructions troublesome. As Swan explains, '[u]nfortunately the exact differences between the three structures [the third one is noun + noun-S.M.] are complicated and difficult to analyse - this is one of the most difficult areas of English grammar. $<\ldots>$ In order to be certain which structure is used to express a particular idea, it is necessary to consult a good dictionary' [Swan 1995: 379].

\section{Russian genitive alternation}

No mention of this topic was found in literature, but in the Russian language a pair of constructions exists that is very similar to English genitive alternation in terms of function, structure, and semantics. These constructions are noun + noun in genitive case and relative adjective derived from noun + noun:

(3) $r u k-a \quad m a m-y$

hand-NOM mother-GEN

'mother's hand' / 'hand of mother'

(4) mam-in-a ruk-a

mother-ADJ-NOM hand-NOM

'mother's hand' / 'hand of mother'

To the best of our knowledge, the distribution of this pair has not been studied previously. The present paper attempts to support two following hypotheses:

(a) The higher up the referent of the modifier is in the animacy hierarchy, the more likely it is that the noun + noun in genitive case construction will be used.

(b) The lower down the referent of the modifier is in the animacy hierarchy, the more likely it is that the relative adjective derived from noun + noun construction will be used.

In other words, the paper attempts to support the animacy hierarchy account for both the English and Russian languages.

\section{Data and methodology}

The present analysis presupposes two consecutive steps. First, we want to establish an inter-language comparability of two pairs of constructions in English and in Russian. Second, we will test the similarity of intra-language distribution of each pair of constructions from the perspective of the animacy hierarchy.

For these two purposes, two types of corpora are needed:

(a) A translation corpus consisting of original texts in one language and their translations into one or more languages [see Granger et al. 2003]; and

(b) A national corpora consisting of original texts in two respective languages.

Contrastive linguists generally deal with comparable corpora, that is, corpora consisting of original texts, matched by criteria such as the time of composition, text category, and intended audience [Johansson and Hasselgård 1999, Granger et al. 2003], but since we are in search of typological evidence, there is no need to use comparable corpora for our purposes. 
For a translation corpus, the current study used the OpenSubtitles2016 containing 2.8 million subtitle files in 60 languages for a total of over 17 billion tokens in 2.6 billion sentences [Lison and Tiedemann 2016]. For two national corpora, British National Corpus and Russian National Corpus were used for English and Russian respectively.

\section{Comparability of constructions}

Theoretically speaking, only three variants of association can exist between English and Russian genitive alternations (see Table 1):

Table 1

Three variants of association between English and Russian genitive alternations

\begin{tabular}{|c|c|c|}
\hline & English & Russian \\
\hline \multirow{2}{*}{ A } & S-genitive & Noun + noun in genitive case \\
\cline { 2 - 3 } & Of-genitive & Relative adjective derived from noun + noun \\
\hline \multirow{2}{*}{ B } & S-genitive & Relative adjective derived from noun + noun \\
\cline { 2 - 3 } & Of-genitive & Noun + noun in genitive case \\
\hline C & & No association \\
\hline
\end{tabular}

(a) This variant predicts that English $s$-genitives will be translated into Russian mostly by means of the noun + noun in genitive case construction while ofgenitives will be translated mostly with the relative adjective derived from noun + noun construction.

(b) This variant foreshadows the reverse situation, predicting that English $s$ genitives will be translated into Russian mostly by means of the relative adjective derived from noun + noun construction while of-genitives will be translated mostly with the noun + noun in genitive case construction.

(c) This variant predicts that no association will be found between the English $s$-genitives and of-genitives and the Russian noun + noun in genitive case and relative adjective derived from noun + noun constructions (null hypothesis).

To test these hypotheses, two English words were chosen that Gries and Stefanowitsch list among the most distinctive collexemes of two constructions (the present study is concerned only with modifiers, not heads): women for s-genitive (distinctiveness score $=0.0003$ ) and life for of-genitive (distinctiveness score $=$ 1.58E-21) [Gries and Stefanowitsch 2004: 116]. The first 100 unique $s$-genitive and of-genitive examples that included these words were then extracted from the OpenSubtitles2016 corpus, and their Russian translations were analysed. Each Russian sentence was coded as a noun + noun in genitive case construction, relative adjective derived from noun + noun construction, or paraphrase (that is, translated sentence in which neither of the aforementioned constructions is used). The summary is presented in Table 2 . 
English genitive constructions and their Russian translations

\begin{tabular}{|c|c|c|c|}
\hline & $\begin{array}{c}\text { Noun + noun } \\
\text { in genitive case }\end{array}$ & $\begin{array}{c}\text { Relative adjective derived } \\
\text { from noun + noun }\end{array}$ & Paraphrase \\
\hline Women's + noun & 39 & 95 & 32 \\
\hline Noun + of + women & 70 & 18 & 43 \\
\hline Life's + noun & 72 & 33 & 97 \\
\hline Noun + of + life & 125 & 5 & 83 \\
\hline
\end{tabular}

Separate Pearson's Chi-squared tests were conducted for the constructions with women and life. ${ }^{1}$ These tests yielded the following results: $\chi 2=459.602, \mathrm{df}=$ $2, p=1.142 \mathrm{e}-13$ and $\chi^{2}=35.713, \mathrm{df}=2, p=1.758 \mathrm{e}-08$ respectively. The $\mathrm{p}$-value is highly significant in both cases; the null hypothesis of no association between the English $s$-genitives and of-genitives on the one hand and the Russian noun + noun in genitive case and relative adjective derived from noun + noun constructions on the other hand can be rejected.

Although the effect size of the second test is weaker than that of the first one (Cramer's $V$ of 0.293 compared to Cramer's $V$ of 0.448 respectively), standardised Pearson's residuals obtained for each cell in the data frame indicate that the same individual deviations are statistically significant in both cases. $S$-genitives are commonly translated into Russian by means of the relative adjective derived from noun + noun construction, while of-genitives are associated with the noun + noun in genitive case construction.

To visualise the results, the assoc function from the $v c d$ library in R Studio [R Core Team 2013] was used. In Figures 1 and 2, pink shading indicates that individual residuals are significantly underrepresented; blue shading indicates that individual residuals are significantly overrepresented; and grey shading indicates that individual residuals do not differ significantly from their expected values.
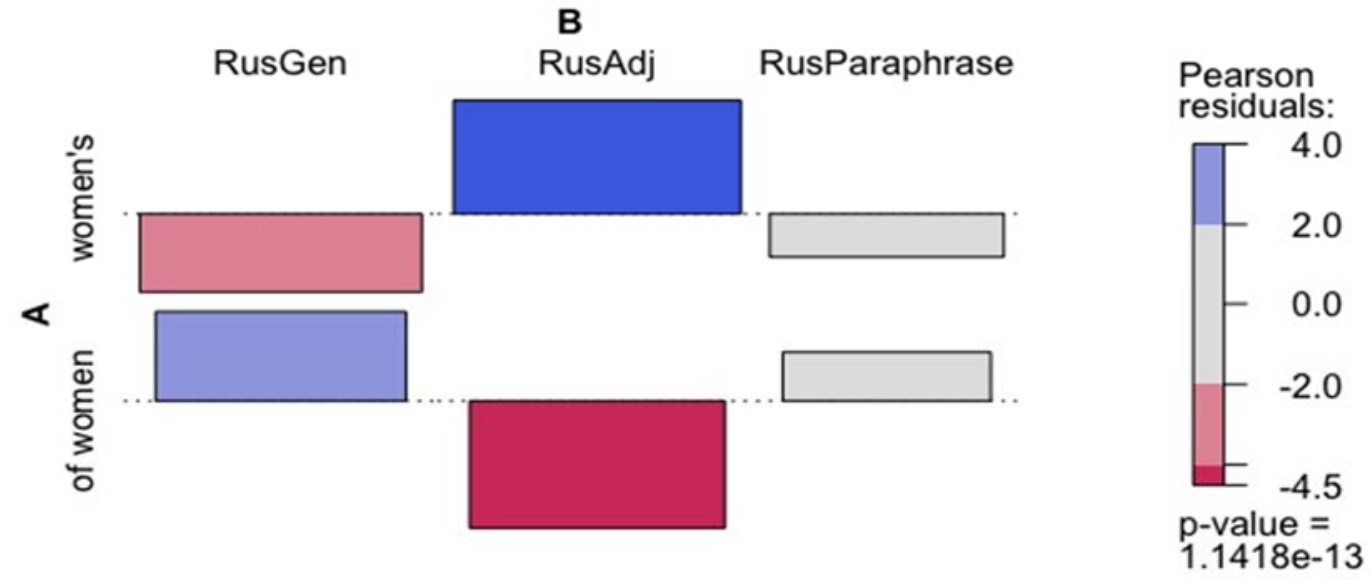

Figure 1. Association plot for the constructions with women

1 All data frames and $\mathrm{R}$ script are downloadable from: https://www.dropbox.com/sh/27gxl3tiow5ljiq/AADMlL-6jJnbe9A9dVRYXJeya?dl=0. 

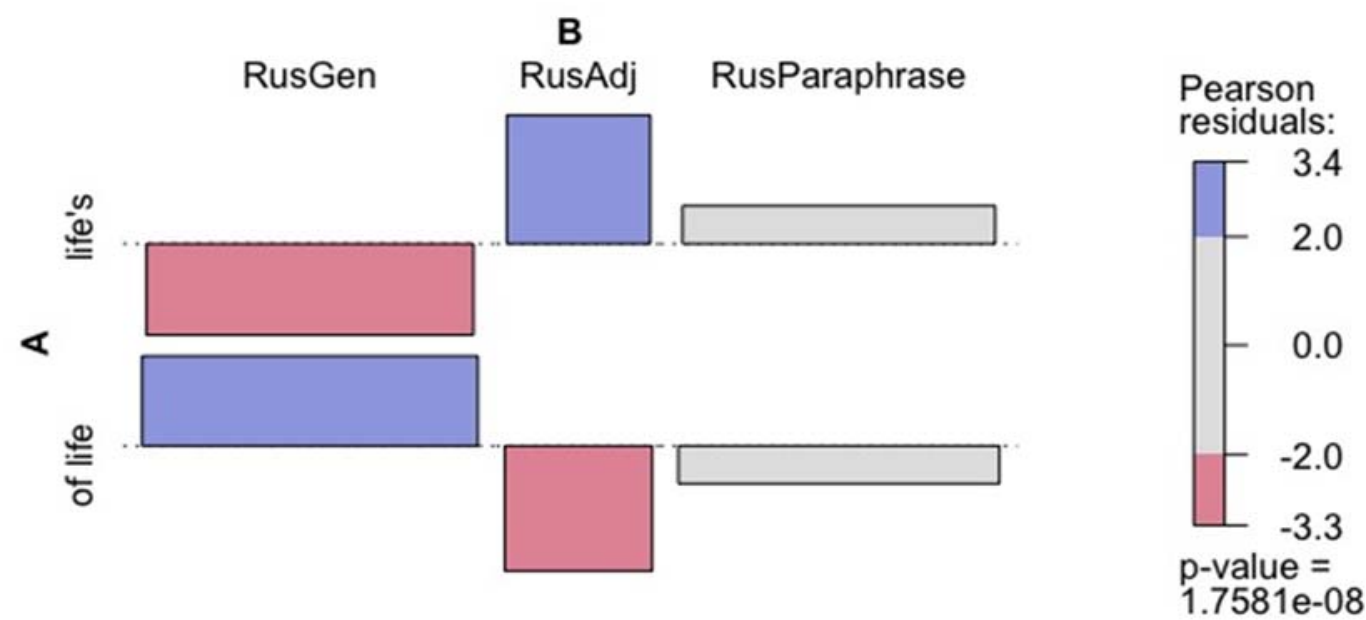

Figure 2. Association plot for the constructions with life

Considering these results, hypothesis (b) appears to be true. In a sense, this finding is counterintuitive. Instead, it would be expected that the English $s$-genitive would be more similar to the Russian true genitive (noun + noun in genitive case) because this construction is the authentic genitive from a historical perspective. However, the word order, namely the linear precedence of a modifier or head in respective constructions, appears to be a powerful factor. The alignment of English and Russian phrases that the present case study has revealed is likely explained by translators' desire to preserve the initial order of constituents (see Table 3).

Table 3

Alignment of English and Russian genitive constructions

\begin{tabular}{|c|c|c|}
\hline & Modifier + head & Head + modifier \\
\hline English & S-genitive & Of-genitive \\
\hline Russian & $\begin{array}{c}\text { Relative adjective derived from } \\
\text { noun + noun }\end{array}$ & Noun + noun in genitive case \\
\hline
\end{tabular}

Overall, the most important finding is the comparability of English and Russian pairs of alternating constructions. This discovery made it possible to proceed with the comparative analysis of their intra-language distribution from the perspective of the animacy hierarchy.

\section{Distribution of constructions}

The animacy hierarchy [Comrie 1981] is 'a scalar representation of types of referents or referring expressions that are ranked according to their deictic, semantic, and/or discourse-pragmatic properties' [Haude and Witzlack-Makarevich 2016: 433]. It is also referred to in the literature as the referential hierarchy [Haude and Witzlack-Makarevich 2016], empathy hierarchy [Kuno and Kaburaki 1977], 
nominal hierarchy [Dixon 1979], indexability hierarchy [Bickel and Nichols 2007], and 'hierarchy of inherent lexical content' [Silverstein 1976].

This hierarchy can be presented in different ways, but the present paper adopted (with the exclusion of all pronouns) the following version provided in [Dixon 1979]:

(5) Proper nouns $>$ human common nouns $>$ animate common nouns $>$ inanimate common nouns

The hypothesis is that both in English and Russian, the closer a modifier is to the left extremity of the scale (5), the more likely it is to be used with the $s$-genitive and relative adjective derived from noun + noun constructions respectively. In contrast, the closer a modifier is to the right extremity of the scale (5), the more likely it is to be used with the of-genitive and noun + noun in genitive case constructions respectively.

To test this hypothesis, four groups of English words were chosen: proper nouns, human common nouns, animate common nouns, and inanimate common nouns. Each group comprised ten different lexemes that are most frequently used as modifiers in $s$-genitive construction, according to the British National Corpus. These lexemes had to satisfy certain criteria in addition to frequency of use:

(a) They had to be used at least once within the English of-genitive construction. ified.

(b) For the group of inanimate common nouns, only concrete nouns were qual-

(c) Their Russian counterparts had to be used at least once within both the relative adjective derived from noun + noun and noun + noun in genitive case constructions. The only exception to this rule was proper nouns that were chosen for each language separately due to reasons of cultural specificity.

(d) The adjectives derived from their Russian counterparts had to retain their literal meaning as the main one. All English candidates leading to metaphorical Russian adjectives and adjectives that are part of terminologised lexical units were excluded.

After that, the raw frequencies of each word were calculated within four respective constructions in the British National Corpus and Russian National Corpus. ${ }^{2}$ The entire dataset is presented in appendices 1 and 2; the summary is provided in Table 4.

Separate Pearson's Chi-squared tests were conducted for all consecutive pairings of groups of nouns in English and Russian moving from the left extremity of the scale (5) to the right. The standardised Pearson's residuals for each cell are presented in Tables 5 to 7 .

\footnotetext{
${ }^{2}$ Since we are not making any intra-corpus comparisons, there is no need to use normalised frequencies.
} 
Raw frequencies of English and Russian genitive constructions

\begin{tabular}{|c|c|c|c|c|}
\hline & \multicolumn{2}{|c|}{ English } & \multicolumn{2}{c|}{ Russian } \\
\cline { 2 - 5 } & S-genitive & Of-genitive & $\begin{array}{c}\text { Noun + noun in } \\
\text { genitive case }\end{array}$ & $\begin{array}{c}\text { Relative adjective derived } \\
\text { from noun + noun }\end{array}$ \\
\hline Proper nouns & 1,084 & 262 & 23,031 & 8,576 \\
\hline $\begin{array}{c}\text { Human } \\
\text { common nouns }\end{array}$ & 3,615 & 1,128 & 44,774 & 19,756 \\
\hline $\begin{array}{c}\text { Animate } \\
\text { common nouns }\end{array}$ & 1,369 & 1,056 & 25,674 & 12,870 \\
\hline $\begin{array}{c}\text { Inanimate } \\
\text { common nouns }\end{array}$ & 773 & 2,002 & 52,887 & 55,151 \\
\hline
\end{tabular}

Table 5

Proper nouns and human common nouns in genitive alternation

\begin{tabular}{|c|c|c|c|c|}
\hline & \multicolumn{2}{|c|}{ English } & \multicolumn{2}{c|}{ Russian } \\
\cline { 2 - 5 } & S-genitive & Of-genitive & $\begin{array}{c}\text { Noun + noun in } \\
\text { genitive case }\end{array}$ & $\begin{array}{c}\text { Relative adjective derived } \\
\text { from noun + noun }\end{array}$ \\
\hline Proper nouns & 3.33064 & -3.33064 & 11.12437 & -11.12437 \\
\hline $\begin{array}{c}\text { Human } \\
\text { common nouns }\end{array}$ & -3.33064 & 3.33064 & -11.12437 & 11.12437 \\
\hline $\begin{array}{c}\text { Pearson's Chi- } \\
\text { squared test }\end{array}$ & \multicolumn{2}{|c|}{$\chi 2=10.849, \mathrm{df}=1, p=<0.001$} & $\chi 2=123.58, \mathrm{df}=1, p=<2.2 \mathrm{e}-16$ \\
\hline
\end{tabular}

Human common nouns and animate common nouns in genitive alternation

\begin{tabular}{|c|c|c|c|c|}
\hline & \multicolumn{2}{|c|}{ English } & \multicolumn{2}{c|}{ Russian } \\
\cline { 2 - 5 } & S-genitive & Of-genitive & $\begin{array}{c}\text { Noun + noun in } \\
\text { genitive case }\end{array}$ & $\begin{array}{c}\text { Relative adjective derived } \\
\text { from noun + noun }\end{array}$ \\
\hline $\begin{array}{c}\text { Human } \\
\text { common nouns }\end{array}$ & 17.20047 & -17.20047 & 9.268528 & -9.268528 \\
\hline $\begin{array}{c}\text { Animate } \\
\text { common nouns }\end{array}$ & -17.20047 & 17.20047 & -9.268528 & 9.268528 \\
\hline $\begin{array}{c}\text { Pearson's Chi- } \\
\text { squared test }\end{array}$ & $\chi 2=294.92, \mathrm{df}=1, p=<2.2 \mathrm{e}-16$ & $\chi 2=85.777, \mathrm{df}=1, p=<2.2 \mathrm{e}-16$ \\
\hline
\end{tabular}

Table 7

Animate common nouns and inanimate common nouns in genitive alternation

\begin{tabular}{|c|c|c|c|c|}
\hline & \multicolumn{2}{|c|}{ English } & \multicolumn{2}{c|}{ Russian } \\
\cline { 2 - 5 } & S-genitive & Of-genitive & $\begin{array}{c}\text { Noun + noun in } \\
\text { genitive case }\end{array}$ & $\begin{array}{c}\text { Relative adjective derived } \\
\text { from noun + noun }\end{array}$ \\
\hline $\begin{array}{c}\text { Animate } \\
\text { common nouns }\end{array}$ & 20.90222 & -20.90222 & 59.67713 & -59.67713 \\
\hline $\begin{array}{c}\text { Inanimate common } \\
\text { nouns }\end{array}$ & -20.90222 & 20.90222 & -59.67713 & 59.67713 \\
\hline $\begin{array}{c}\text { Pearson's Chi- } \\
\text { squared test }\end{array}$ & $\chi 2=435.72, \mathrm{df}=1, p=<2.2 \mathrm{e}-16$ & $\chi 2=3560.7, \mathrm{df}=1, p=<2.2 \mathrm{e}-16$ \\
\hline
\end{tabular}


The same picture is evident across Tables 5 to 7: the first lines indicate overrepresentation of $s$-genitives in English and noun + noun in genitive case constructions in Russian (positive values of standardised Pearson's residuals). These lines also indicate the underrepresentation of of-genitives in English and relative adjective derived from noun + noun constructions in Russian (negative values of standardised Pearson's residuals). In the second lines, the picture is reversed: $s$ genitives and noun + noun in genitive case constructions are underrepresented in English and Russian respectively. Of-genitives and relative adjective derived from noun + noun constructions are overrepresented in English and Russian respectively.

All results are highly significant, and the English part of the hypothesis can be considered true. The closer a modifier is to the left extremity of the scale (5), the more likely it is to be used with $s$-genitive. On the other hand, the closer a modifier is to the right extremity of the scale (5), the more likely it is to be used with ofgenitive. This is not surprising; the present analysis has merely replicated the findings of other numerous studies.

It is interesting that in Russian, the same animacy hierarchy governs the distribution of a similar alternating pair of constructions. Surprisingly, the expectations about the alignment of English and Russian pairs were not met. The linear order of modifier and head that we considered a strong predictor was abandoned in favour of the notion of true, or inflectional, 'genetiveness' on the one hand and periphrastic, or analytical, 'genetiveness' on the other. For this reason, it was necessary to rearrange Table 8 as follows:

Table 8

Rearranged alignment of English and Russian genitive constructions

\begin{tabular}{|c|c|c|}
\hline & Inflectional 'genetiveness' & Analytical 'genetiveness' \\
\hline English & S-genitive & Of-genitive \\
\hline Russian & Noun + noun in genitive case & Relative adjective derived from noun + noun \\
\hline
\end{tabular}

\section{Animacy continuum}

When the significance of the association between the English and Russian pairs of constructions is measured along the whole animacy continuum and not pairwise, it is clear that the two languages, though similar in their general adherence to the hierarchical principle, have different cut-off points on this scale.

The results are visualised in Figures 3 and 4: the pink shading indicates that individual residuals are significantly underrepresented; the blue shading indicates that individual residuals are significantly overrepresented; and the grey shading indicates that individual residuals do not differ significantly from their expected values.

In English (Figure 3), the differential attribute is 'humanness'. The borderline is drawn between groups of proper nouns and human common nouns on the one hand (preferably used with $s$-genitives) and animate common nouns and inanimate 
common nouns on the other (preferably used with of-genitives). In Russian (Figure 4) the differential attribute is 'animateness'. The borderline is drawn between groups of proper nouns, human common nouns, and animate common nouns on the one hand (preferably used with the noun + noun in genitive case construction), and inanimate common nouns, on the other (preferably used with the relative adjective derived from noun + noun construction).

B

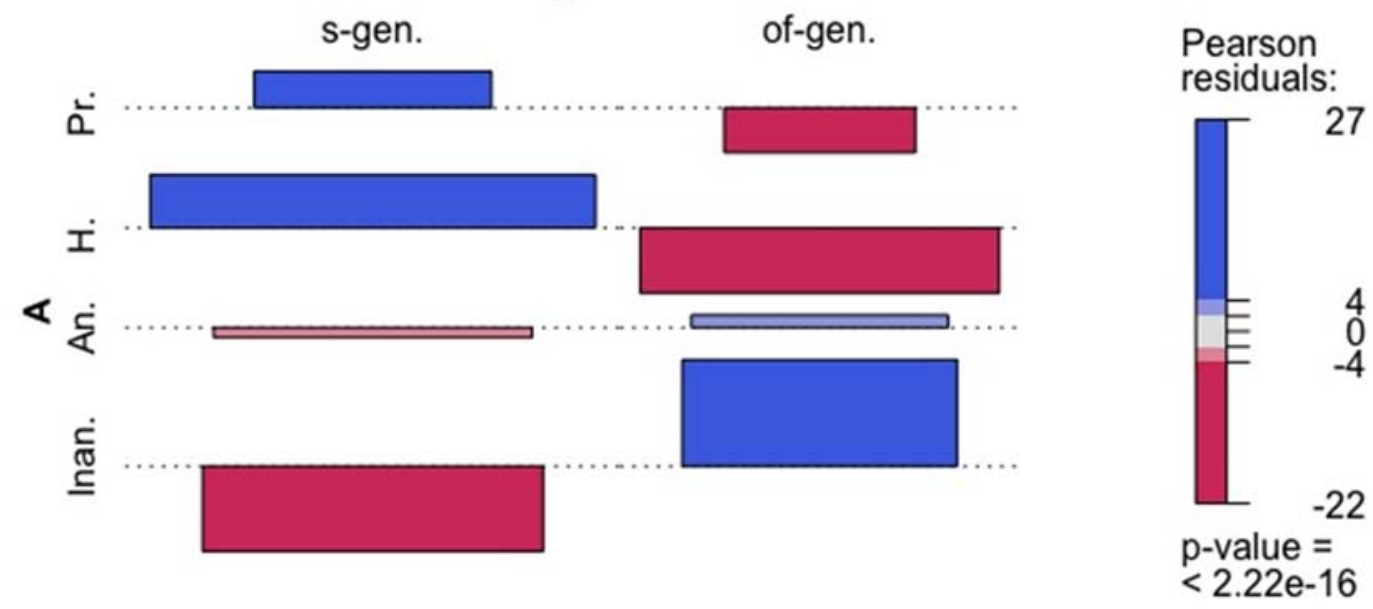

Figure 3. English genitive alternation along the animacy continuum (Cramer's V = 0.41)

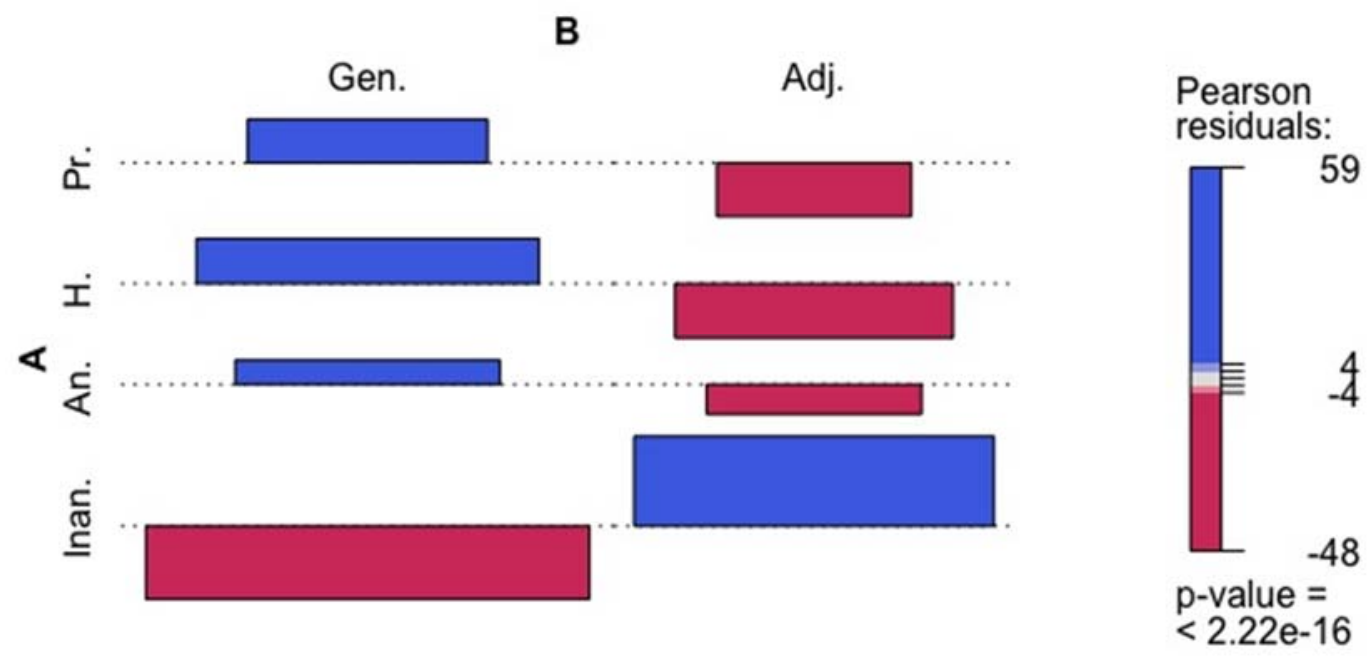

Figure 4. Russian genitive alternation along the animacy continuum (Cramer's V $=0.21$ )

\section{Collostructional strength}

Since our analysis of English and Russian genitive alternations is essentially an examination of alternating pairs of constructions and relative preferences for words that can occur in them, a collostructional analysis of the data was also con- 
ducted. The collostructional analysis, also referred to as distinctive-collexeme analysis, is a method proposed in [Gries and Stefanowitsch 2004] for identifying words that appear in particular slots of constructions rather than any words within a given span.

The coll.analysis package for R Studio was used to calculate the collostructional strengths of 40 English and 40 Russian words in the data [Gries 2007]; the log-likelihood ratio was chosen as an index of association strength (other measures accessible in the coll.analysis package yield comparable results). The output for the English data is presented in Figure 5 and the output for the Russian data is displayed in Figure 6 . In both cases, the lines for each construction are sorted from the highest index of collostructional strengths to the lowest. The higher index, the stronger preference a given lexeme reveals for a particular construction. The red lines in both figures divide the output into four equal parts consisting of 10 lines each.

\begin{tabular}{|c|c|c|c|c|c|c|c|c|c|}
\hline 38 & computer & 133 & 570 & 426.009655 & 276.990345 & OF. GENITIVE & -0.1087058799 & -0.44447792 & 547.2987481 \\
\hline 40 & cigarette & 1 & 57 & 35.147312 & 22.852688 & OF.GENITIVE & -0.0126685707 & -0.59178720 & 97.5101351 \\
\hline 35 & apple & 5 & 58 & 38.177252 & 24.822748 & OF. GENITIVE & -0.0123086810 & -0.52957844 & 78.5301760 \\
\hline 39 & tree & 28 & 88 & 70.294623 & 45.705377 & OF. GENITIVE & -0.0156912038 & -0.36839425 & 64.4250906 \\
\hline 33 & car & 251 & 279 & 321.173709 & 208.826291 & OF. GENITIVE & -0.0260342778 & -0.13892555 & 39.8206666 \\
\hline 37 & book & 191 & 173 & 220.579679 & 143.420321 & OF.GENITIVE & -0.0109739901 & -0.08397038 & 10.2123513 \\
\hline 11 & driver & 435 & 25 & 278.754540 & 181.245460 & S. GENITIVE & 0.0579666913 & 0.35409247 & 297.5167810 \\
\hline 15 & reader & 335 & 23 & 216.943751 & 141.056249 & S. GENITIVE & 0.0437985856 & 0.34056619 & 213.0048427 \\
\hline 13 & doctor & 623 & 124 & 452.673133 & 294.326867 & S.GENITIVE & 0.0631908594 & 0.24417153 & 195.0423541 \\
\hline 17 & manager & 428 & 65 & 298.752148 & 194.247852 & S. GENITIVE & 0.0479506433 & 0.27413786 & 171.8807539 \\
\hline 14 & farmer & 238 & 11 & 150.891044 & 98.108956 & S. GENITIVE & 0.0323172138 & 0.35772547 & 171.6512286 \\
\hline 1 & Shakespeare & 374 & 121 & 299.964124 & 195.035876 & S.GENITIVE & 0.0274671324 & 0.15642641 & 51.5969760 \\
\hline 21 & cow & 153 & 29 & 110.289840 & 71.710160 & S. GENITIVE & 0.0158453671 & 0.23851655 & 48.3393408 \\
\hline 16 & master & 325 & 103 & 259.362920 & 168.637080 & S. GENITIVE & 0.0243511995 & 0.15940104 & 46.7342576 \\
\hline 3 & Tolkien & 99 & 12 & 67.264682 & 43.735318 & S. GENITIVE & 0.0117737268 & 0.28874285 & 45.8629922 \\
\hline 5 & Kipling & 51 & 2 & 32.117371 & 20.882629 & S. GENITIVE & 0.0070054101 & 0.35795657 & 37.9174739 \\
\hline 28 & cat & 203 & 58 & 158.162902 & 102.837098 & S. GENITIVE & 0.0166344559 & 0.17585540 & 35.6586822 \\
\hline 18 & teacher & 549 & 234 & 474.488706 & 308.511294 & S. GENITIVE & 0.0276435116 & 0.10225356 & 32.9910048 \\
\hline 10 & Spenser & 53 & 4 & 34.541323 & 22.458677 & S. GENITIVE & 0.0068481248 & 0.32547983 & 31.7062918 \\
\hline 25 & snatl & 52 & 5 & 34.541323 & 22.458677 & S. GENITIVE & 0.0064771272 & 0.30784694 & 27.6362952 \\
\hline 26 & goat & 77 & 14 & 55.144920 & 35.855080 & S. GENITIVE & 0.0081081824 & 0.24211741 & 25.2580428 \\
\hline 8 & Wilde & 46 & 8 & 32.723359 & 21.276641 & S.GENITIVE & 0.0049256020 & 0.24704544 & 15.7457999 \\
\hline 4 & Chaucer & 62 & 14 & 46.055098 & 29.944902 & S. GENITIVE & 0.0059155205 & 0.21122335 & 15.6711671 \\
\hline 22 & spider & 67 & 17 & 50.903003 & 33.096997 & S. GENITIVE & 0.0059719473 & 0.19306751 & 14.2642908 \\
\hline
\end{tabular}

Figure 5. Distinctive-collexeme analysis of the English data

Though it is necessary to allow for the idiosyncratic behaviour of different words in the two languages, the results of the distinctive-collexeme analysis largely support our previous findings. Inanimate common nouns constitute the majority of words that display the strongest preference for analytical genitives (the of-genitive 
in English and the relative adjective derived from noun + noun construction in Russian). Human common nouns constitute the majority of words that demonstrate the strongest preference for inflectional genitives (the $s$-genitive in English and the noun + noun in genitive case construction in Russian).

There are, however, discrepancies suggesting that at least some levels of the animacy hierarchy form a continuum. Words with referents that are conceived of as more prototypically animate demonstrate a stronger preference for inflectional genitives than words from the same group with referents that are less prototypically animate. This tendency is most observable with animate common nouns that occupy the intermediate position between undoubtedly animate human beings and undoubtedly inanimate physical objects.

\begin{tabular}{|c|c|c|c|c|c|c|c|c|c|}
\hline \multirow[b]{2}{*}{31} & \multicolumn{4}{|c|}{ words obs.freq.1 obs.freq. 2} & \multicolumn{5}{|c|}{ exp.freq. 2 pref.occur delta.p.constr.to.word delta.p.word.to.constr coll.strength } \\
\hline & kamen_kamennyj & 3903 & 19431 & 14071.02140 & 9262.97860 & ADJECTIVE & -0.1749986831 & -0.482107738 & $2.077895 \mathrm{e}+64$ \\
\hline 39 & derevo_derevannyj & 9626 & 19641 & 17648.77790 & 11618.22210 & ADJECTIVE & -0.1380775581 & -0.311709549 & $1.022901 \mathrm{e}+04$ \\
\hline 38 & kompjuter_kompjuternyj & 1306 & 4033 & 3219.55872 & 2119.44128 & ADJECTIVE & -0.0329336695 & -0.366472611 & $2.897173 \mathrm{e}+03$ \\
\hline 29 & svinja_svinoj & 1243 & 1624 & 1728.87710 & 1138.12290 & ADJECTIVE & -0.0083622811 & -0.171498044 & $3.385752 \mathrm{e}+02$ \\
\hline 20 & predatel_predatelskij & 445 & 750 & 720.61672 & 474.38328 & ADJECTIVE & -0.0047435545 & -0.231782765 & $2.593912 \mathrm{e}+02$ \\
\hline 32 & kukla_kukolnyj & 731 & 922 & 996.80288 & 656.19712 & ADJECTIVE & -0.0045746514 & -0.161902904 & $1.749155 \mathrm{e}+02$ \\
\hline 14 & fermer_fermerskij & 295 & 499 & 478.80308 & 315.19692 & ADJECTIVE & -0.0031633781 & -0.232249773 & $1.733279 \mathrm{e}+02$ \\
\hline 28 & koshka_koshachij & 1460 & 1440 & 1748.77698 & 1151.22302 & ADJECTIVE & -0.0049700516 & -0.100782415 & $1.190473 \mathrm{e}+02$ \\
\hline 34 & bulavka_bulavochnyj j & 172 & 177 & 210.45626 & 138.54374 & ADJECTIVE & -0.0006618589 & -0.110348536 & $1.732915 \mathrm{e}+01$ \\
\hline 21 & korova_korovij & 1908 & 1312 & 1941.74548 & 1278.25452 & ADJECTIVE & -0.0005807830 & -0.010620862 & $1.492882 \mathrm{e}+00$ \\
\hline$\overline{33}$ & mashina_mashinnyj & 14289 & 1840 & 9726.21515 & 6402.78485 & GENITIVE & 0.0785286841 & 0.303029971 & $6.785843 \mathrm{e}+03$ \\
\hline 23 & loshad_loshadinyj & 8631 & 2488 & 6705.05215 & 4413.94785 & GENITIVE & 0.0331468949 & 0.181528162 & $1.572695 \mathrm{e}+03$ \\
\hline 12 & president_presidentskij & 11683 & 4016 & 9466.91373 & 6232.08627 & GENITIVE & 0.0381403779 & 0.150922617 & $1.475275 \mathrm{e}+03$ \\
\hline 18 & uchitel_uchitelskij & 5797 & 1419 & 4351.43955 & 2864.56045 & GENITIVE & 0.0248790955 & 0.206465296 & $1.368965 \mathrm{e}+03$ \\
\hline 37 & kniga_knizhnyj & 17458 & 7165 & 14848.32262 & 9774.67738 & GENITIVE & 0.0449143532 & 0.117951082 & $1.332588 \mathrm{e}+03$ \\
\hline 13 & doktor_doktorskij & 5237 & 1402 & 4003.49323 & 2635.50677 & GENITIVE & 0.0212295049 & 0.191022025 & $1.070190 \mathrm{e}+03$ \\
\hline 15 & chitatel_chitatelskij & 4298 & 1118 & 3265.99177 & 2150.00823 & GENITIVE & 0.0177615757 & 0.194896954 & $9.168812 \mathrm{e}+02$ \\
\hline 6 & Lomonosov_lomonosovskij & 1591 & 169 & 1061.32672 & 698.67328 & GENITIVE & 0.0091160436 & 0.303148916 & $8.133530 \mathrm{e}+02$ \\
\hline 8 & Chehov_chehovskij & 4605 & 1550 & 3711.62839 & 2443.37161 & GENITIVE & 0.0153755436 & 0.148922120 & $5.895329 \mathrm{e}+02$ \\
\hline 7 & Pasternak_pasterankovskifi & 1275 & 162 & 866.54915 & 570,45085 & GENITIVE & 0.0070297218 & 0.285931427 & $5.797916 \mathrm{e}+02$ \\
\hline 36 & trava_travanoj & 2620 & 788 & 2055.11447 & 1352.88553 & GENITIVE & 0.0097220709 & 0.168113264 & $4.262393 \mathrm{e}+02$ \\
\hline 17 & menedzher_menedzherskij & 703 & 72 & 467.34557 & 307.65443 & GENITIVE & 0.0040557757 & 0.305044233 & $3.658786 \mathrm{e}+02$ \\
\hline 40 & sigareta_sigaretnyj & 1475 & 357 & 1104.74463 & 727.25537 & GENITIVE & 0.0063723511 & 0.203641509 & $3.470145 \mathrm{e}+02$ \\
\hline 3 & Bulgakov_bulgakovskij & 1119 & 220 & 807.45254 & 531.54746 & GENITIVE & 0.0053619473 & 0.233962430 & $3.438004 \mathrm{e}+02$ \\
\hline 2 & Nekrasov_nekrasovskij & 1169 & 245 & 852.67953 & 561.32047 & GENITIVE & 0.0054440941 & 0.225017002 & $3.331911 \mathrm{e}+02$ \\
\hline 10 & Gogol_gogolevskij & 3801 & 1520 & 3208.70425 & 2112.29575 & GENITIVE & 0.0101938197 & 0.113807813 & $2.935669 \mathrm{e}+02$ \\
\hline 9 & Turgenev_turgenevskij & 1569 & 523 & 1261.53153 & 830.46847 & GENITIVE & 0.0052917450 & 0.148251235 & $2.023967 \mathrm{e}+02$ \\
\hline 30 & ryba_rybij & 4035 & 1834 & 3539.16279 & 2329.83721 & GENITIVE & 0.0085337014 & 0.086577569 & $1.846917 \mathrm{e}+02$ \\
\hline 5 & Derzhavin_derzhavinskij & 577 & 121 & 420.91253 & 277.08747 & GENITIVE & 0.0026863734 & 0.224265953 & $1.639046 \mathrm{e}+02$ \\
\hline 26 & kozel_kozlinyjj & 1361 & 483 & 1111.98095 & 732.01905 & GENITIVE & 0.0042857901 & 0.136076679 & $1.494747 \mathrm{e}+02$ \\
\hline 25 & ulitka_ulitkin & 157 & 1 & 95.27819 & 62.72181 & GENITIVE & 0.0010622750 & 0.390898800 & $1.486139 \mathrm{e}+02$ \\
\hline 24 & ptica_ptichij & 6202 & 3363 & 5767.94890 & 3797.05110 & GENITIVE & 0.0074703197 & 0.047240750 & $8.687149 \mathrm{e}+01$ \\
\hline 4 & Pelevin_pelevinskij & 79 & 1 & 48.24212 & 31.75788 & GENITIVE & 0.0005293643 & 0.384600219 & $7.102802 \mathrm{e}+01$ \\
\hline 1 & Pushkin_pushkinskij & 7246 & 4065 & 6820.83325 & 4490.16675 & GENITIVE & 0.0073174139 & 0.039426089 & $7.082236 \mathrm{e}+01$ \\
\hline 22 & pauk_pauchij & 373 & 159 & 320.81012 & 211.18988 & GENITIVE & 0.0008982239 & 0.098316769 & $2.222542 \mathrm{e}+01$ \\
\hline 11 & voditel_voditelskij & 1295 & 754 & 1235.60139 & 813.39861 & GENITIVE & 0.0010222912 & 0.029235877 & $7.319209 \mathrm{e}+00$ \\
\hline 27 & kaban_kabanij & 304 & 166 & 283.42248 & 186.57752 & GENITIVE & 0.0003541534 & 0.043866909 & $3.824253 \mathrm{e}+00$ \\
\hline 35 & jabloko_jablochnyj & 1307 & 797 & 1268.76785 & 835.23215 & GENITIVE & 0.0006580017 & 0.018330067 & $2.943415 e+00$ \\
\hline 19 & soldat_soldatskij & 10495 & 6799 & 10428.74107 & 6865.25893 & GENITIVE & 0.0011403620 & 0.004125254 & $1.142990 \mathrm{e}+00$ \\
\hline 16 & master_masterskij & 4526 & 2927 & 4494.35684 & 2958.64316 & GENITIVE & 0.0005446007 & 0.004380194 & $5.796869 \mathrm{e}-01$ \\
\hline
\end{tabular}

Figure 6. Distinctive-collexeme analysis of the Russian data

Table 9 illustrates that as a result of conceptual 'deanimisation' an animate common noun can even cross the threshold between two constructions and start displaying a preference for the analytical genitive. Importantly, the data suggest that this continuum is charted in varying ways in the two languages. It seems that in English, less prototypically animate animals are those that humans normally use for food (pig, boar, bird, fish). In Russian, less prototypically animate animals are those that were historically omnipresent in peasant households (korova 'cow', koshka 'cat', svinja 'pig'). 
Prototypical animacy in English and Russian

\begin{tabular}{c|c|c}
\multicolumn{2}{c|}{ English } & Russian \\
\hline More & Horse & Loshad 'horse' \\
prototypical & Cow & Ryba 'fish' \\
& Cat & Kozel 'goat' \\
& Snail & Ulitka 'snail' \\
& Goat & Ptica 'bird' \\
& Spider & Pauk 'spider' \\
& Pig & Kaban 'boar' \\
\cline { 2 - 2 } & Boar & Korova 'cow' \\
Less & Bird & Koshka 'cat' \\
\cline { 2 - 3 } & Fish & Svinja 'pig' \\
\hline
\end{tabular}

To test this hypothesis, two more pairings of English and Russian animate common nouns were selected: $\operatorname{dog}$ (sobaka/sobachij) and rabbit (krolik/krolichij). They met all the requirements specified above and could be expected to display distinctively different preferences for genitive constructions.

Dog (sobaka) denotes an animal that is uneatable and highly important for a country life. As a result, this word is likely to be conceptualised as more prototypical in English and less prototypical in Russian. In contrast, rabbit (krolik) denotes an animal that is universally used for food and exotic to the traditional Russian peasantry. It is likely to be conceptualised as less prototypical in English and more prototypical in Russian.

As before, the collostructional strengths of two new sets of English and Russian animate common nouns were calculated using the coll.analysis package for $\mathrm{R}$ Studio; the log-likelihood ratio was again chosen as an index of association strength. The output for the English data is presented in Figure 7, and the output for Russian data is included in Figure 8.

\begin{tabular}{|c|c|c|c|c|c|c|c|c|c|}
\hline 3 & horse & 385 & 107 & 287.19458 & 204.80542 & S.GENITIVE & 0.13644369 & 0.23858216 & 102.627201 \\
\hline 11 & dog & 314 & 120 & 253.33831 & 180.66169 & S.GENITIVE & 0.08462624 & 0.16388386 & 42.607127 \\
\hline 5 & snail & 52 & 5 & 33.27254 & 23.72746 & S.GENITIVE & 0.02612578 & 0.33502526 & 31.363400 \\
\hline 6 & goat & 77 & 14 & 53.11932 & 37.88068 & S.GENITIVE & 0.03331480 & 0.27077784 & 30.123384 \\
\hline 7 & boar & 40 & 8 & 28.01898 & 19.98102 & S. GENITIVE & 0.01671415 & 0.25373306 & 14.037693 \\
\hline 4 & bird & 202 & 121 & 188.54441 & 134.45559 & S. GENITIVE & 0.01877126 & 0.04678022 & 2.615386 \\
\hline
\end{tabular}

Figure 7. Distinctive-collexeme analysis of the English data (animate common nouns)

Our prediction is borne out. The English dog and Russian krolik display a strong preference for the $s$-genitive and noun + noun in genitive case construction respectively, which means that these words are located high on the animacy hierarchies. At the same time, the English rabbit and Russian sobaka show strong preference for of-genitive and relative adjective derived from noun + noun construction 
respectively, which means that the positions of these words on the animacy hierarchies are relatively low.

\begin{tabular}{|c|c|c|c|c|c|c|c|c|c|}
\hline 8 & koshka_koshachij & 1460 & 1440 & 1851.3691 & 1048.6309 & ADJECTIVE & -0.0342348695 & -0.143349373 & 234.2269580 \\
\hline 1 & korova_korovij & 1908 & 1312 & 2055.6581 & 1164.3419 & ADJECTIVE & -0.0129163382 & -0.049045572 & 30.8928548 \\
\hline 3 & loshad_loshadinyj & 8631 & 2488 & 7098.4044 & 4020.5956 & GENITIVE & 0.1340632419 & 0.177743961 & 1247.4333171 \\
\hline 5 & ulitka_ulitkin & 157 & 1 & 100.8677 & 57.1323 & GENITIVE & 0.0049101531 & 0.356404862 & 131.1105698 \\
\hline 6 & kozel_kozlinyj & 1361 & 483 & 1177.2154 & 666.7846 & GENITIVE & 0.0160764933 & 0.103520985 & 86.4519667 \\
\hline 10 & ryba_rybij & 4035 & 1834 & 3746.7880 & 2122.2120 & GENITIVE & 0.0252112411 & 0.055709857 & 70.8884087 \\
\hline 12 & krolik_krolichij & 626 & 236 & 550.3035 & 311.6965 & GENITIVE & 0.0066215238 & 0.089370584 & 30.5585544 \\
\hline 2 & pauk_pauchij & 373 & 159 & 339.6305 & 192.3695 & GENITIVE & 0.0029189878 & 0.063405835 & 9.4303034 \\
\hline 4 & ptica_ptichij & 6202 & 3363 & 6106.3260 & 3458.6740 & GENITIVE & 0.0083690506 & 0.012396936 & 5.1539703 \\
\hline 7 & kaban_kabanij & 304 & 166 & 300.0495 & 169.9505 & GENITIVE & 0.0003455709 & 0.008485914 & 0.1457156 \\
\hline
\end{tabular}

Figure 8. Distinctive-collexeme analysis of the Russian data (animate common nouns)

\section{Conclusion}

This paper began with a presentation of five different accounts of genitive alternation in English: the hypotheses of the animacy hierarchy, given-new hierarchy, topic-focus hierarchy, end-weight principle, and two semantically distinct constructions.

Stefanowitsch, who is the proponent of the last and most recent new account ${ }^{3}$ [Stefanowitsch 2003], argues that all other explanations fail because they rely heavily on the linearisation hierarchy. In the case of the $s$-genitive, the hypotheses make correct predictions (modifier $=$ the first word). However, in the case of the of-genitive, the hypotheses are refuted because of the conflict that exists between the linear order and the syntactic structure of the phrase (modifier $\neq$ the first word).

However, Stefanowitsch's own alternative hypothesis, when tested, did not cross the threshold of statistical significance [Stefanowitsch 1998: 25]. Many findings, including those of the present study, indicate that the distribution of the two English genitives does not depend on any semantic relationships encoded by these constructions. Even indiscriminate, coarse-grained approaches such as the one in the present study reveal the absolutely distinct patterns of the partial paraphrase relationship between $s$-genitive and $o f$-genitive.

The comparison of the distribution of the two English and two Russian genitives was insightful. It was established that in both languages the choice between members of an alternating pair is governed by the rules of animacy hierarchisation. Additionally, it was possible to disprove the idea that the animacy hierarchy is necessarily based on the linearisation hierarchy. The two Russian constructions are typologically aligned with their English counterparts, not on the grounds of the linear order of head and modifier but on the grounds of structural similarity. The English $s$-genitive and Russian noun + noun in genitive case construction are diametrically opposed in terms of word order. However, they reveal the same underlying structure of the inflectional genitive as contrasted with the analytical genitive of the Russian

${ }^{3}$ Other more recent studies in this field, to the best of our knowledge, can be subsumed under one of the abovementioned accounts. 
relative adjective derived from noun + noun construction and the English of-genitive.

This study is just a preliminary one, very selective (also with regard to the source of the research material) and can only be regarded as the first step to undertake a more comprehensive research on genitive alternation in English and Russian (explored through translational and non-translational data).

(C) Sergei Monakhov, 2020
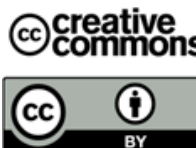

This work is licensed under a Creative Commons Attribution 4.0 International License https://creativecommons.org/licenses/by/4.0/

\section{REFERENCES}

Altenberg, Bengt. 1980. Binominal NPs in a thematic perspective: Genitive vs. of-constructions in 17th century English. In S. Jacobson (ed.), Papers from the Scandinavian Symposium on Syntactic Variation. Stockholm Studies in English 52, 149-172. Stockholm: Almqvist and Wiksell.

Bickel, Balthasar \& Johanna Nichols, J. 2007. Inflectional morphology. In Timothy Shopen (ed.), Language typology and syntactic description, 169-240 Cambridge: Cambridge University Press.

Comrie, Bernard. 1981. Language universals and linguistic typology: Syntax and morphology. Oxford: Blackwell.

Croft, William. 2001. Radical construction grammar: syntactic theory in typological perspective. Oxford: Oxford University Press.

Deane, Paul D. 1992. Grammar in Mind and Brain. Explorations in Cognitive Syntax. Berlin and New York: Mouton de Gruyter.

Diessel, Holger. 2019. The Grammar Network: How Linguistic Structure is Shaped by Language Use. Cambridge: Cambridge University Press.

Dixon, Robert M. W. 1979. Ergativity. Language 55. 59-138.

Fillmore, Charles J., Paul Kay \& Mary Catherine O’Connor. 1988. Regularity and idiomaticity in grammatical constructions: The case of let alone. Language 64 (3). 501-538.

Gast, Volker. 2015. On the use of translation corpora in contrastive linguistics. A case study of impersonalization in English and German. Languages in Contrast 15 (1). 4-33.

Goldberg, Adele. 2006. Constructions at Work: The nature of Generalizations in Language. Oxford: Oxford University Press.

Goldberg, Adele. 2002. Surface generalizations: An alternative to alternations. Cognitive Linguistics 13 (3). 327-356.

Goldberg, Adele. 1995. A Construction Grammar Approach to Argument Structure. Chicago: University of Chicago Press.

Granger, Sylviane, Jacques Lerot \& Stephanie Petch-Tyson (eds). 2003. Corpus-Based Approaches to Contrastive Linguistics and Translation Studies. Amsterdam: Rodopi.

Gries, Stefan Th. 2007. Coll.analysis 3.2a. A program for $R$ for Windows 2.x.

Gries, Stefan Th. \& Anatol Stefanowitsch. 2004. Extending Collostructional Analysis: A Corpus-Based Perspective on 'Alternations.' International Journal of Corpus Linguistics 9 (1). 97-129. 
Haude, Katharina \& Alena Witzlack-Makarevich. 2016. Referential hierarchies and alignment: An overview. Linguistics 54(3). 433-441.

Hawkins, John A. 1994. A Performance Theory of Order and Constituency. Cambridge, New York, Oakleigh: Cambridge University Press.

Hawkins, Roger. 1981. Towards an account of the possessive constructions: NP's N and the N of NP. Journal of Linguistics 17. 247-269.

Hilpert, Martin. 2014. Construction Grammar and its Application to English. Edinburgh: Edinburgh University Press.

Jespersen, Otto. 1949. A Modern English Grammar on Historical Principles. Vol. 7: Syntax. Copenhagen: Munksgaard.

Johansson, Stig \& Hilde Hasselgård. 1999. Corpora and cross-linguistic research in the Nordic countries. Le Langage et l'Homme. Special issue: Contrastive linguistics and translation. 34 (1). $145-162$.

Jørgensen, Erik. 1984. 'Of + personal pronoun' used as possessive and subjective genitives about persons. English Studies 65. 52-58.

Kuno, Susumu and Etsuko Kaburaki. 1977. Empathy and Syntax. Linguistic Inquiry 8(4). $627-672$.

Langacker, Ronald W. 2009. Cognitive (Construction) Grammar. Cognitive Linguistics 20/1. $167-176$.

Lison, Pierre \& Jörg Tiedemann. 2016. OpenSubtitles2016: Extracting Large Parallel Corpora from Movie and TV Subtitles. In Proceedings of the Tenth International Conference on Language Resources and Evaluation (LREC 2016), 923-929. Paris: European Language Resources Association.

Lyngfelt, Benjamin, Borin, Lars, Ohara, Kyoko, \& Timponi Torrent, Tiago. (eds). 2018. Constructicography. Constructicon development across languages. Amsterdam: John Benjamins.

McArthur, Roshan \& Thomas Burns McArthur. 2005. Concise Oxford Companion to the English Language. Oxford: Oxford University Press.

Osselton, Noel E. 1988. Thematic genitives. In G. Nixon and J. Honey (eds.), An Historic Tongue: Studies in English Linguistics in Memory of Barbara Strang, 138 - 144. London: Routledge.

Pawley, Andrew \& Syder, Frances Hodgetts. 1983. Two puzzles for linguistic theory: nativelike selection and nativelike fluency. In Jack C. Richards, R. W. Schmidt (eds.), Language and Communication, 191-226. London: Routledge.

R Core Team. 2013. R: A Language and Environment for Statistical Computing. R Foundation for Statistical Computing, Vienna, Austria. Available at http://www.R-project.org/ [last accessed December 2019].

Siewierska, Anna. 1988. Word Order Rules. London, New York, Sydney: Croom Helm.

Silverstein, Michael. 1976. Hierarchy of features and ergativity. In Robert M. W. Dixon (ed.), Grammatical categories in Australian languages, 112-171. Atlantic Highlands, NJ: Humanities Press.

Standwell, Graham. 1982. Genitive constructions and Functional Sentence Perspective. International Review of Applied Linguistics 20. 257-261.

Stefanowitsch, Anatol. 2003. Constructional semantics as a limit to grammatical alternation: The two genitives in English. In G. Rohdenburg \& B. Mondorf (eds.), Determinants of grammatical variation in English, 413-444. Berlin and New York: Mouton de Gruyter.

Stefanowitsch, Anatol. 1998. Possession and partition: The two genitives of English. Cognitive Linguistics: Explorations, Applications, Research. Working Papers of the English Department at Hamburg University 23. 1-30.

Swan, Michael. 1995. Practical English Usage. Oxford: Oxford University Press. 


\section{Data sources:}

British National Corpus. Available online at $<$ https://www.english-corpora.org/bnc/ $>$. May 2019.

OpenSubtitles2016. Available online at <http://opus.nlpl.eu/OpenSubtitles2016.php>. May 2019.

Russian National Corpus. Available online at <www.ruscorpora.ru>. May 2019.

\section{Appendix 1}

\begin{tabular}{|c|c|c|c|}
\hline & noun & $S$-genitive & of-genitive \\
\hline \multirow{11}{*}{ Proper nouns } & Shakespeare & 374 & 121 \\
\hline & Milton & 107 & 56 \\
\hline & Tolkien & 99 & 12 \\
\hline & Chaucer & 62 & 14 \\
\hline & Kipling & 51 & 2 \\
\hline & Tennyson & 38 & 8 \\
\hline & Byron & 44 & 13 \\
\hline & Wilde & 46 & 8 \\
\hline & Wordsworth & 210 & 24 \\
\hline & Spenser & 53 & 4 \\
\hline & TOTAL & 1084 & 262 \\
\hline \multirow{11}{*}{$\begin{array}{c}\text { Human common } \\
\text { nouns }\end{array}$} & driver & 435 & 25 \\
\hline & president & 570 & 531 \\
\hline & doctor & 623 & 124 \\
\hline & farmer & 238 & 11 \\
\hline & reader & 335 & 23 \\
\hline & master & 325 & 103 \\
\hline & manager & 428 & 65 \\
\hline & teacher & 549 & 234 \\
\hline & soldier & 109 & 11 \\
\hline & traitor & 3 & 1 \\
\hline & TOTAL & 3615 & 1128 \\
\hline \multirow{11}{*}{$\begin{array}{c}\text { Animate common } \\
\text { nouns }\end{array}$} & cow & 153 & 29 \\
\hline & spider & 67 & 17 \\
\hline & horse & 385 & 107 \\
\hline & bird & 202 & 121 \\
\hline & snail & 52 & 5 \\
\hline & goat & 77 & 14 \\
\hline & boar & 40 & 8 \\
\hline & cat & 203 & 58 \\
\hline & pig & 104 & 35 \\
\hline & fish & 86 & 662 \\
\hline & TOTAL & 1369 & 1056 \\
\hline \multirow{7}{*}{$\begin{array}{c}\text { Inanimate common } \\
\text { nouns }\end{array}$} & stone & 74 & 393 \\
\hline & doll & 83 & 2 \\
\hline & car & 251 & 279 \\
\hline & pin & 6 & 21 \\
\hline & apple & 5 & 58 \\
\hline & grass & 1 & 361 \\
\hline & book & 191 & 173 \\
\hline
\end{tabular}


Sergei Monakhov. 2020. Russian Journal of Linguistics 24 (1). 96-116

\begin{tabular}{|l|l|c|c|}
\hline & \multicolumn{1}{|c|}{ noun } & $s$-genitive & of-genitive \\
\hline \multirow{4}{*yyy}{} & computer & 133 & 570 \\
\cline { 2 - 4 } & tree & 28 & 88 \\
\cline { 2 - 4 } & cigarette & 1 & 57 \\
\cline { 2 - 4 } & TOTAL & $\mathbf{7 7 3}$ & $\mathbf{2 0 0 2}$ \\
\hline
\end{tabular}

\section{Appendix 2}

\begin{tabular}{|c|c|c|c|}
\hline & noun / adjective & $\begin{array}{c}\text { noun }+ \text { noun in } \\
\text { genitive case }\end{array}$ & $\begin{array}{l}\text { relative adjective derived } \\
\text { from noun }+ \text { noun }\end{array}$ \\
\hline \multirow{11}{*}{$\begin{array}{l}\text { Proper } \\
\text { nouns }\end{array}$} & Pushkin / pushkinskij & 7246 & 4065 \\
\hline & Nekrasov/nekrasovskij & 1169 & 245 \\
\hline & Bulgakov / bulgakovskij & 1119 & 220 \\
\hline & Pelevin / pelevinskij & 79 & 1 \\
\hline & Derzhavin / derzhavinskij & 577 & 121 \\
\hline & Lomonosov / lomonosovskij & 1591 & 169 \\
\hline & Pasternak / pasterankovskij & 1275 & 162 \\
\hline & Chehov / chehovskij & 4605 & 1550 \\
\hline & Turgenev / turgenevskij & 1569 & 523 \\
\hline & Gogol' / gogolevskij & 3801 & 1520 \\
\hline & TOTAL & 23031 & 8576 \\
\hline \multirow{11}{*}{$\begin{array}{l}\text { Human } \\
\text { common } \\
\text { nouns }\end{array}$} & voditel' / voditel'skij & 1295 & 754 \\
\hline & president / presidentskij & 11683 & 4016 \\
\hline & doktor / doktorskij & 5237 & 1402 \\
\hline & fermer / fermerskij & 295 & 499 \\
\hline & chitatel' / chitatel'skij & 4298 & 1118 \\
\hline & master / masterskij & 4526 & 2927 \\
\hline & menedzher / menedzherskij & 703 & 72 \\
\hline & uchitel' / uchitel'slij & 5797 & 1419 \\
\hline & soldat / soldatskij & 10495 & 6799 \\
\hline & predatel' / predatel'skij & 445 & 750 \\
\hline & TOTAL & 44774 & 19756 \\
\hline \multirow{11}{*}{$\begin{array}{l}\text { Animate } \\
\text { common } \\
\text { nouns }\end{array}$} & korova / korovij & 1908 & 1312 \\
\hline & pauk / pauchij & 373 & 159 \\
\hline & loshad' / loshadinyj & 8631 & 2488 \\
\hline & ptica / ptichij & 6202 & 3363 \\
\hline & ulitka / ulitkin & 157 & 1 \\
\hline & kozel / kozlinyj & 1361 & 483 \\
\hline & kaban / kabanij & 304 & 166 \\
\hline & koshka / koshachij & 1460 & 1440 \\
\hline & svinja / svinoj & 1243 & 1624 \\
\hline & ryba / rybij & 4035 & 1834 \\
\hline & TOTAL & 25674 & 12870 \\
\hline \multirow{7}{*}{$\begin{array}{l}\text { Inanimate } \\
\text { common } \\
\text { nouns }\end{array}$} & kamen' / kamennyj & 3903 & 19431 \\
\hline & kukla / kukol'nyj & 731 & 922 \\
\hline & mashina / mashinnyj & 14289 & 1840 \\
\hline & bulavka / bulavochnyj & 172 & 177 \\
\hline & jabloko / jablochnyj & 1307 & 797 \\
\hline & trava / trav'anoj & 2620 & 788 \\
\hline & kniga / knizhnyj & 17458 & 7165 \\
\hline
\end{tabular}


Sergei Monakhov. Russian Journal of Linguistics. 2020. T. 24. № 1. C. 96-116

\begin{tabular}{|l|l|c|c|}
\hline \multicolumn{1}{|c|}{ noun / adjective } & $\begin{array}{c}\text { noun + noun in } \\
\text { genitive case }\end{array}$ & $\begin{array}{c}\text { relative adjective derived } \\
\text { from noun + noun }\end{array}$ \\
\hline \multirow{2}{*}{} & kompjuter / kompjuternyj & 1306 & 4033 \\
\cline { 2 - 4 } & derevo / derev'annyj & 9626 & 19641 \\
\cline { 2 - 4 } & sigareta / sigaretnyj & 1475 & 357 \\
\cline { 2 - 4 } & TOTAL & $\mathbf{5 2 8 8 7}$ & $\mathbf{5 5 1 5 1}$ \\
\hline
\end{tabular}

\section{Article history:}

Received: 28 June 2019

Revised: 15 August 2019

Accepted: 29 November 2019

\section{История статьи:}

Дата поступления в редакцию: 28 июня 2019

Дата принятия к печати: 29 ноября 2019

\section{Bionote:}

SERGEI MONAKHOV, Friedrich-Schiller-Universität Jena (Germany), PhD student. Research interests: computer linguistics, corpus linguistics, construction grammar, linguistic typology.

\section{Contact information:}

E-mail: sergei.monakhov@uni-jena.de

ORCID 0000-0002-0759-9998

\section{Сведения об авторе:}

СЕРГЕЙ МОНАХОВ, аспирант Йенского университета имени Фридриха Шиллера (Германия). Научные интересы: компьютерная лингвистика, корпусная лингвистика, грамматика конструкций, лингвистическая типология.

Контактная информация:

E-mail: sergei.monakhov@uni-jena.de

ORCID 0000-0002-0759-9998 